\title{
EHMTI-0135. Migraine outcomes and cortical excitability: analysis of pattern-reversal visual evoked potentials (PR-VEP)
}

\author{
A Sergeev ${ }^{*}$ E Snopkova, G Tabeeva, V Osipova \\ From 4th European Headache and Migraine Trust International Congress: EHMTIC 2014 \\ Copenhagen, Denmark. 18-21 September 2014
}

\section{Introduction}

Outcomes of migraine (M) in the elderly as well as agerelated neurophysiological changes are poorly studied.

Aim of study was to evaluate cortical excitability changes in $\mathrm{M}$ patients depending on patient's age and M outcome.

\section{Methods}

Study groups comprised: 20 young (aged 20-49, YM) and 35 elderly pts (aged 50-70, EM) with ongoing typical M attacks; 11 elderly pts (aged 50-70) with complete $M$ cessation by now and typical $M$ course in the past (No more $M$ ) and 7 pts of any age with partial $M$ cessation (preservation of $\mathrm{M}$ aura without headache) - Late Life Migraine Equivalents (LLME). Diagnosis was based on ICHD-2, 2004. Control groups: healthy subjects without headache ( $\mathrm{n}=15$ aged $20-49, \mathrm{n}=15$ aged $50-70)$. The RP-VEP test was carried out in a period free from migraine attacks.

\section{Results}

Significant increase in total N75-P100 $(\mathrm{p}<0,05)$ and more marked dyshabituation were obtained in YM $(7,74 \pm 2,7$ and $-8.1 \%)$, EM $(7,85 \pm 3,9$ and $-2.3 \%)$ and LLME groups $(8.7 \pm 2.5$ and $-0.76 \%)$ compared to group no more $M$ $(5.6 \pm 1,5)$ and both control groups without $\mathrm{M}$ anamnesis $(6,85 \pm 2,6$ and $-14.4 \% ; 6,24 \pm 2,6$ and $-15.1 \%)$.

\section{Conclusions}

Our study has shown that patients with active $M$ and those keeping $M$ aura but shedding headache phase (LLME) demonstrate neurophysiological pattern typical for $\mathrm{M}$ reflecting cortical hyperexcitability which could be

Department of Neurology, I.M. Sechenov First Moscow State Medical University, Moscow, Russia

(c) 2014 Sergeev et al; licensee Springer. This is an Open Access article distributed under the terms of the Creative Commons Attribution License (http://creativecommons.org/licenses/by/2.0), which permits unrestricted use, distribution, and reproduction in any medium, provided the original work is properly cited. the basis for M preservation in any age. On the contrary, in patients of any age with complete $M$ cessation we revealed complete normalization of both indexes which appeared comparable to subjects who never suffered from $M$.

No conflict of interest.

Published: 18 September 2014

doi:10.1186/1129-2377-15-S1-E34

Cite this article as: Sergeev et al.: EHMTI-0135. Migraine outcomes and cortical excitability: analysis of pattern-reversal visual evoked potentials (PR-VEP). The Journal of Headache and Pain 2014 15(Suppl 1):E34.

Submit your manuscript to a SpringerOpen ${ }^{\mathcal{O}}$ journal and benefit from:

- Convenient online submission

- Rigorous peer review

- Immediate publication on acceptance

- Open access: articles freely available online

- High visibility within the field

- Retaining the copyright to your article

Submit your next manuscript at $\boldsymbol{\sim}$ springeropen.com 